\title{
PERAN PEREMPUAN BUGIS PERSPEKTIF HUKUM KELUARGA ISLAM
}

\author{
Musyfikah Ilyas \\ Fakultas Syariah dan Hukum UIN Alauddin Makassar \\ musyfikahilyas@uin-alauddin.ac.id
}

\begin{abstract}
This study discusses the role of Bugis women in the perspective of Islamic family law, using library research. The identity of the Bugis woman is siri ', sipakatau, sipakalebbi, sipakainge. The role of the Bugis woman was mapped into two parts, first the role of the Bugis woman as a leader. Second, the role of Bugis women as wives and mothers. The perspective of Islamic family law regulates that the role of the Bugis woman both in the household and in the public sphere, her teachings continue to promote justice, equality and democracy.
\end{abstract}

Keywords: Bugis Women, Bugis Culture, Islamic Family Law

\section{A. PENDAHULUAN}

Suku Bugis atau to ugi adalah salah satu suku yang berdomisili di Sulawesi Selatan. Ciri utama kelompok etnik ini adalah bahasa dan adat istiadat. Peradaban awal orang-orang bugis juga dipengaruhi oleh tokohtokohnya yang hidup di masa lalu. Di ceritakan dalam karya sastra yang termuat di dalam La Galigo atau sure'galigo. Keberadaan sosok perempuan bugis dalam karya sastra tersebut tidak dapat dipungkiri menjadi bagian besar dari perkembangan sejarah orang bugis pada masa itu.

Keberadaan sosok perempuan bugis dalam karya La Galigo seperti We' Opu Sengngeng, We' Tenri Abeng dan We' Cudai merupakan tokoh perempuan bugis yang mewarnai corak pemerintahan dan perkembangan perempuan bugis yang merdeka yang merupakan titik awal munculya perempuan bugis sebagai partnership suami dalam menjalankan pemerintahannya. Dalam lontaraq juga dijelaskan nasihat-nasihat bijak sebagai penuntun orang-orang bugis dalam mengarungi kehidupan, isinya cenderung pada pesan yang mengatur norma sosial, bagaimana berhubungan dengan sesama baik yang berlaku pada masyarakat setempat maupun orang bugis di perantauan.

Perempuan bugis dalam naskah lontaraq, ditemukan posisi perempuan bugis dalam tradisi berperan tidak saja sebagai simbol kejelitaan atau pengasuh rumah tangga bagi suami dan anak-anaknya namun ikut mendominasi pranata sosial masyarakat dan politik. Perempuan bugis di dalam lontara bugis disebut materru na' malampe nawa-nawa (Berani dan memiliki visi). Dan perempuan bugis digambarkan sebagai dewi kehidupan (Sang Hyang Seri) sosok paling dihormati yang mengatur, kesejahteraan manusia di muka bumi, posisi 
perempuan bugis sebagai seorang istri yang taat terhadap suaminya, memegang teguh nilai-nilai agama, dan mencintai suaminya yang dicitrakan sebagai perempuan penurut dan setia, seperti tokoh St.Saerah dan I Darmatasia, Perempuan dicitrakan sebagai ahli agama dan wali, perempuan dicitrakan sebagai cendekiawan, pemberani, dan pejuang yang mempunyai jiwa spirit perjuangan yang tinggi tergambar dalam sosok Colli Pujie.

Sejarah Sulawesi telah memberikan sudut pandang betapa orang bugis disatu sisi sangat menghormati dan menjaga perempuan, namun disisi lain memberikan ruang untuk menduduki posisi strategis. Sementara sistem kekerabatan bilateral memberi kita petunjuk tentang kesetaraan relasi gender perempuan bugis. Dalam rangka pemberdayaan perempuan, tentu perlu pembacaan yang cermat terhadap konteks sosial budaya bersangkutan sebelum meretas (re)solusi pemberdayaan perempuan. Kurang tepat jika kiranya asumsi "penindasan perempuan" pada budaya tertentu dilekatkan pada budaya bugis.

Setelah diterimanya Islam dalam masyarakat bugis, transformasi perempuan bugis mulai beradaptasi, nuansa kehidupan islami baik dari adat istiadat, perilaku sosial dan sistem pemerintahan lambat tapi pasti mempengaruhi prinsip-prinsip perempuan bugis dalam kehidupan kesehariannya. Pranata sosial yang ada sedikit demi sedikit membuat perempuan bugis semakin kokoh dengan adanya persamaan hak antara lakilaki dan perempuan dalam Islam, diterimanya Islam sebagai agama masyarakat bugis karena sebagai besar norma-norma sosial masyarakat bugis tidak bertentangan dengan Islam.

Perempuan bugis terus berkiprah dan menjadi perempuan yang tangguh pada masanya. Kiprah perempuan bugis sekarang menyebar di berbagai profesi dan keahlian, ada yang menjadi pengusaha sukses, anggota parlemen, akademisi, politikus dan birokrasi tanpa mengurangi kodratnya sebagai istri dan ibu dari anak-anaknya. Kesemuanya ini tidak terlepas dari sistem sosial yang berlaku disatu sisi dan regulasi negara yang turut memperhatikan keterwakilan dan pemberdayaan perempuan. Oleh karena itu keberadaan hukum Islam sebagai filter dalam setiap perilaku dan tindakan perempuan bugis sangat mempengaruhi dalam kehidupan sosial kemasyarakatan. Kemudian munculnya regulasi-regulasi negara yang mengatur tentang perempuan serta munculnya keadilan dan kesetaraan gender yang bukan tidak mungkin menimbukan kesalah pahaman persepsi dan multi tafsir regulasi yang ada sehingga dapat menimbulkan eksepsi dan legitimasi yang berbeda. Oleh karena itu dalam penelitian ini akan dijelaskan tentang bagaimana hukum keluarga Islam terhadap peran perempuan bugis.

\section{B. METODE PENELITIAN}

Penelitian menggunakan kualitatif dalam proses pengumpulan data menggunakan kepustakaan yakni: membaca dan mencatat literatur yang berkaitan dengan perempuan bugis, kaidah-kaidah perempuan bugis yang disadur dari berbagai referensi, memaknai dan memadukan hasil bacaan, menganalis dengan menggunakan perspektif hukum kelarga Islam. Tahap 
analisis, yakni melakukan pemilahan dari data yang dikumpulkan, selanjutnya display data sehingga memberikan pemahaman terhadap data dan langkah terakhir konklusi sebagai dasar mendapat hasil yang maksimal.

\section{PEMBAHASAN \\ Hukum Keluarga Islam}

Hukum Islam dalam konteks keindonesian menurut Ahmad Rofiq adalah peraturan-peraturan yang diambil dari wahyu dan diformulasikan dalam empat produk pemikiran hukum, yakni fikih, fatwa, keputusan pengadilan dan undang-undang yang dipedomani dan diberlakukan bagi umat Islam Indonesia. ${ }^{1}$ Hukum keluarga adalah hukum yang mengatur perihal hubungan hukum internal anggota keluarga dalam keluarga tertentu yang berhubungan dengan ihwal kekeluargaan. ${ }^{2}$ Menurut Wahbah Zuhaili, ${ }^{3}$ hukum keluarga Islam diistilahkan al-aḥwaāl al-syakhșiyyah mengatur tentang hubungan keluarga pada awal keluarga itu dibentuk mulai dari pernikahan, perceraian, keturunan, nafkah dan kewarisan. Selanjutnya Ahmad al-Zarqa membatasi ruang lingkup hukum keluarga meliputi tiga macam subtansi hukum yaitu : (1) perkawinan (al-munākahāât), dan hal-hal dengannya; (2) perwalian dan wasiat (al-walāyah wal wașayā), (3) kewarisa (al-mawāriś). ${ }^{4}$ Dan dikembangkan menjadi empat subtansi oleh Muhammad Suma yakni (1) perkawinan (2) pengasuhan dan pemeliharaan anak (haḍānah) (3) Kewarisan dan wasiat (al-walāyah wal wașāyā), (4) perwalian dan pengampuan pengawasan (al-walāyah wal hajr). ${ }^{5}$ Berdasarkan konsep di atas di maka yang di maksud hukum keluarga Islam adalah mengatur segala hal yang bertalian dengan aturan pribadi dan keluarga yang berhubungan dengan ihwal keluarga.

\section{Identitas Perempuan Bugis}

Dari segi identitas perempuan bugis menurut penulis dapat dipetakan menjadi empat bagian yaitu siri', sipakatau, sipakalebbi, sipakainge yang dijadikan sebagai identitas masyarakat bugis ${ }^{6}$. Siri' merupakan adat kebiasaan yang melembaga dan masih besar pengaruhnya dalam budaya kehidupan masyarakat Sulawesi Selatan, disamping nilai positifnya juga dapat melahirkan problem sosial apabila siri' tidak lagi menjadi identitas perempuan bugis.

Berbagai ungkapan dalam Bahasa bugis yang terwujud dalam kesusastraan, paseng dan amanat-amanat dari leluhurnya, yang dapat dijadikan petunjuk tentang siri' itu pada orang bugis:

${ }^{1}$ Ahmad Rofiq, Hukum Islam Indonesia, Edisi I (Cet. III; Jakarta: Pt. Raja Grafindo Persada, 1998), h. 9.

${ }^{2}$ Muhammad Amin Suma, Hukum Keluarga Islam di Dunia Islam (Jakarta: PT RajaGrafindo Persada, 2005), h. 16.

${ }^{3}$ Wāhbah al Zuhailî, al-Fiqh al-Islāmī wa Adillatuh (Beirūt-Lubhān: Dār al-Fikr, 1989), h. 19.

${ }^{4}$ Muhammad Amin Suma, Hukum Keluarga Islam di Dunia Islam, h. 22

${ }_{6}^{5}$ Muhammad Amin Suma, Hukum Keluarga Islam di Dunia Islam, h. 23.

${ }^{6}$ Hamid Abdullah, Manusia Bugis Makassar Suatu Tinjauan Historis Pola Tingka Laku dan PAndangan Hidup Manusia Bugis Makassar (Cet. I; Jakarta: Inti Idayu Press, 1985), h. 37 


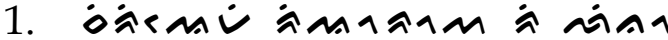

Siri'emmi rionrang ri lino, artinya, hanya untuk siri' itu sajalah kita hidup di dunia. Dalam ungkapan ini termaktub arti siri' sebagai hal yang memberi identitas sosial dan martabat kepada seseorang, hanya kalau ada martabat atau harga diri, hidup ada artinya.

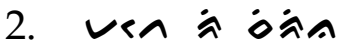

Mate ri Siri'na, artinya mati dalam siri' yakni mati demi menegakkan martabat atau harga diri, mati yang demikian dianggap suatu hal yang terpuji dan terhormat.

3. Vर八 ò

Mate Siri', artinya orang yang sudah hilang harga dirinya dan tak lebih dari bangkai hidup. ${ }^{7}$

Siri' yang diberi makna harga diri, seorang manusia tidak menjaga harga dirinya adalah manusia yang tidak bermartabat, dalam hal ini perempuan yang tidak konsekuen menegakkan siri' dalam dirinya. Dengan sendirirnya terjadilah hal-hal atau tindakan-tindakan yang sebenarnya bertentangan dengan jiwanya sendiri.

Perempuan bugis dan kebudayaan telah berhasil memancarkan nilai-nilai yang terdapat dalam masyarakat dan kebudayaan bugis. Berbagai nilai mulai tampil pada permukaan melatarbelakangi berbagai pola perilaku-kehidupan masyarakat dan kebudayaan bugis, baik secara implisit maupun secara eksplisit, nilai-nilai itu telah menunjukkan unsur-unsur esensial bagi wujud suatu masyarakat.

Perempuan bugis menggambarkan tentang pembentukan persekutuan sosial, tentang kepercayaan dan tatacara yang membimbing dan mengawasi setiap kegiatan regulatif, tentang komunikasi yang dipergunakan untuk menyimpan pikiran dan perasaan dalam interaksi sosial, dan tentang apa yang dipandang mulia dan patut bagi setiap tingkah laku atau dalam mengambil sikap terhadap situasi-situasi tertentu. Oleh Raymond Firth, ${ }^{8}$ keempat-empat komponen tersebut, masing-masing disebutnya social aligrument, social control, social media, dan social standars.

Sipakatau adalah kehidupan sosial yang memandang manusia sebagai manusia seutuhnya dalam kondisi apapun, saling menghormati sesama manusia tanpa melihat dia miskin atau kaya atau dalam keadaan apapun. Sipakatau dalam dimensi kognisi sosial diproduksi oleh individual atau kelompok untuk membangun suatu realitas sosial yang harmonis. Dalam konteks sosial budaya dipahami sebagai wacana budaya yang berkembang dalam masyarakat untuk mengeksplorasi ideologi sosial kultural, mengklarifikasi ideologi struktural dari berbagai paradigma. ${ }^{9}$ Selanjutnya sipakalebbi adalah saling menghargai sesama manusia dan yang terakhir

${ }^{7}$ Mattulada, Latoa Satu Lukisan Analitis terhadap Antropologi Politik Orang Bugis (Gadjah Mada University Press 1985), h. 63

${ }^{8}$ Raymond Firth, Elements of Sosial Organization (Boston: Beacon Press, 1961), h. 41

${ }^{9}$ Jufri, Analisis Wacana Budaya (Cet. I; Makassar: Badan Penerbit UNM, 2009), h. 27 
adalah sipakainge yang artinya saling mengingatkan antar sesama manusia dalam kebaikan.

\section{Nilai-Nilai Keberadaan Perempuan Bugis perspektif Hukum Keluarga Islam}

Nilai-nilai kebudayaan bugis tidak terlepas dari nilai-nilai kejujuran, cendekiawan, kepatutan, keteguhan, dan usaha, sebagai nilai-nilai utama yang menjadi tuntutan bagi perempuan bugis dalam pranata sosial. Berikut nilainilai perempuan bugis dalam tataran kemasyarakatan :

\section{a. Perempuan Bugis sebagai Pemimpin}

Pada umumnya kegiatan perempuan berbentuk pelayanan sosial. Kegiatan ini antara lain: menyantuni yatim piatu, anak terlantar, jompo, miskin, meningkatkan taraf hidup kaum wanita yang masih rendah dan mencegah terjadinya kemaksiatan yang berkaitan dengan perempuan. Posisi perempuan secara sosial juga dipandang sebagai penentu bagi kehidupan negara. Perempuan sebagai pendamping suami, perempuan sebagai penggerak sosial kemasyarakatan dan wanita sebagai pendidik anak, generasi muda dan sebagainya, sangat menentukan citra bangsa.

Dualisme peran perempuan antara peran perempuan dalam keluarga dan peran perempuan dalam dunia publik tentu kedua peran tidak kontradiktif namun saling mendukung. Idealnya perempuan mampu mewujudkan kedua perannya tanpa harus mengorbankan salah satu peran.

Perempuan bugis dalam konteks peran publik sebagai anggota masyarakat dan warga negara mempunyai hak bernegara, salah satunya sebagai pemimpin selama memiliki kapasitas, kapabilitas dan akseptabilitas yang menjadi barometer yang harus dikedepankan tanpa meninggalkan kodrat dan identitas sebagai perempuan.

Hal menarik kemudian dalam sejarah dibuktikan bahwa perempuan bugis mampu menopang peran ganda sekaligus. Perempuan bugis ${ }^{10}$ dalam kepemimpinan sudah ada dari dulu sampai sekarang sejarah telah mencatat bahwa naskah Ilagaligo dapat disalin berkat upaya Colli' Puji Arung Pancana Toa, seorang isteri, ibu dan ratu (pemimpin) sekaligus intelektual perempuan dizamannya. Perempuan bugis harus berani, tangguh dalam berjuang sebagaimana disebutkan bahwa:

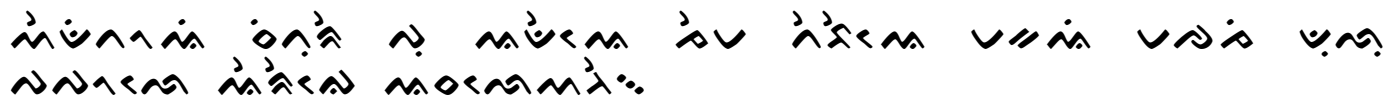

(We'dittoi situnreng pung ade'é Jemma te'be'é mmaka'i mancaji dulung papolé 'enrengngé asaléwangeng). ${ }^{11}$

Terjemahan: Perempuan juga berhak untuk dipilih seluruh rakyat untuk menjadi pemimpin mereka di jalan kemakmuran dan keselamatan.

${ }^{10}$ Christian Pelras, The Bugis, yang diterjemahkan Abdul rahman Abu, dalam judul Manusia Bugis (Jakarta: Nalar bekerjasama dengan Forum Jakarta-Paris, 2005). Lihat juga Rahman Rahim, NilaiNilai Utama Kebudayaan Bugis (Cet. I; Ombak: Yogyakarta, 2011), h. 100

${ }^{11}$ La Paroki, Perempuan Bugis (online), http://www.Identitasonline.net/2012/04/Perempuan-bugis html diunduh 14 januari 2013. 


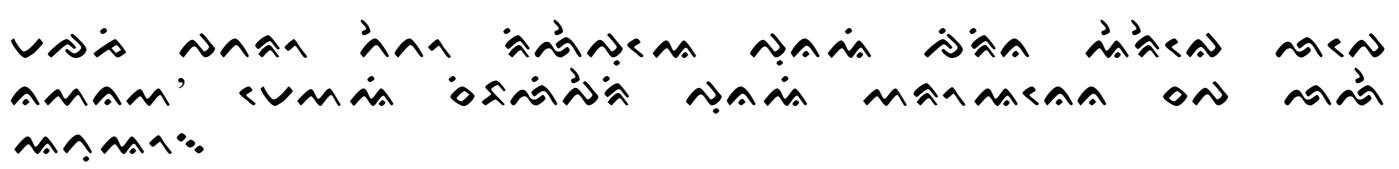

(Mancaji pattaro tettong rílempu'é punnai cirinna engrengé lampe 'Nawa-nawa mméwai sibaliperri' waroanéna 'Sappa 'laleng atuong)

Terjemahan: menjadi penuntun yang jujur, hemat bijaksana sekaligus mitra pendukung dan penopang dalam mengatasi kesulitan maupun perjuangan dalam mengatasi segala hal.

Peran perempuan bugis dalam kanca politik boleh menjadi pemimpin, sepanjang sejarahnya perempuan bugis di Bone tercatat sebanyak tujuh kali mendudukkan raja perempuan di atas tahta kerajaan, namun tidak luput dari bias gender sering terjadi posisi perempuan dianggap memiliki banyak kelemahan dibandingkan laki-laki, baik kelemahan fisik maupun kelemahan mental. Dalam permusyawaratan, perempuan dapat diikutsertakan akan tetapi pendapat atau buah pikirannya, tak dapat dijadikan sesuatu yang prinsipil.

Dalam masyarakat bugis masih berlangsung nilai-nilai utama kebudayaan. Namun kelangsungan hidupnya tidak terlepas dari keadaan masyarakatnya yang senantiasa mengalami perubahan. Reposisi perempuan Bugis mengalami perubahan, perubahan tersebut dilihat dari segi sifatnya dipetakan yakni perubahan yang bersifat meniadakan, perubahan yang bersifat menambah, perubahan yang bersifat menunjang dan perubahan yang bersifat menggabung.

Reposisi perempuan bugis yang dulunya diikutsertakan dalam bermusyawarah hanya sebatas memberikan pendapat, namun kini mengalami perubahan yang bersifat menambah, hal itu berdampak pada keikutsertaan perempuan dalam kancah politik, berdampak pada proses keterlibatan perempuan dalam proses pengambilan keputusan, mengambil kebijakan publik, proses penyelenggaraan negara dan politik perwakilan.

Perempuan sebagai pemimpin dalam pandangan hukum keluarga Islam di bolehkan dengan berdasar pada perempuan dalam Islam mendapat tempat yang mulia, tidak seperti yang dituduhkan. Kedudukan perempuan yang mulia di tegaskan dalam al-Qur'an dan Hadis. Dalam Q.S. Alí 'Imran: 195, Q.S. alAḥzāb: 35, Q.S. al-Taubah: 71. Hadis: Hadis riwayat al-Bukhārî, Muslim, Aḥmad, Abū Dāwūd, al-Tirmiẑî dari Abū al-Zubair.

Q.S. al- Imran/3: 195

Terjemahannya:

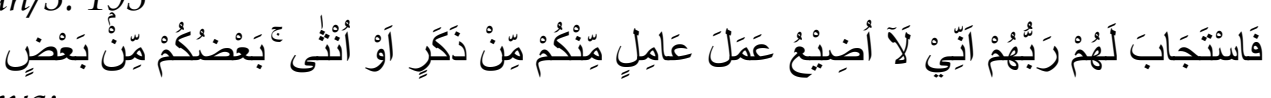

Maka Tuhan mereka memperkenankan permohonannya (dengan berfirman), "Sesungguhnya Aku tidak menyia-nyiakan amal orang yang beramal di antara kamu, baik laki-laki maupun perempuan, (karena) sebagian kamu adalah (keturunan) dari sebagian yang lain. 
Q.S. al-Ahzab/33: 35

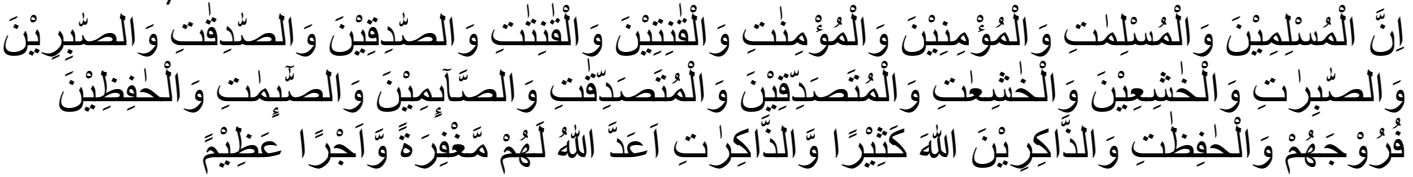

Terjemahan:

Sungguh, laki-laki dan perempuan muslim, laki-laki dan perempuan mukmin, laki-laki dan perempuan yang tetap dalam ketaatannya, laki-laki dan perempuan yang benar, laki-laki dan perempuan yang sabar, laki-laki dan perempuan yang khusyuk, laki-laki dan perempuan yang bersedekah, laki-laki dan perempuan yang berpuasa, laki-laki dan perempuan yang memelihara kehormatannya, laki-laki dan perempuan yang banyak menyebut (nama) Allah, Allah telah menyediakan untuk mereka ampunan dan pahala yang besar.

Q.S. al-Taubah (9) :71

Terjemahan:

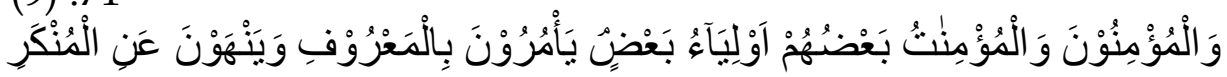

Dan orang-orang yang beriman, laki-laki dan peremuan, sebagian mereka menjadi penolong bagi sebagian yang lain. Mereka menuruh (berbuat) yang makruf dan mencegah dari yang mungkar.

Hadis tentang kepemimpinan perempuan

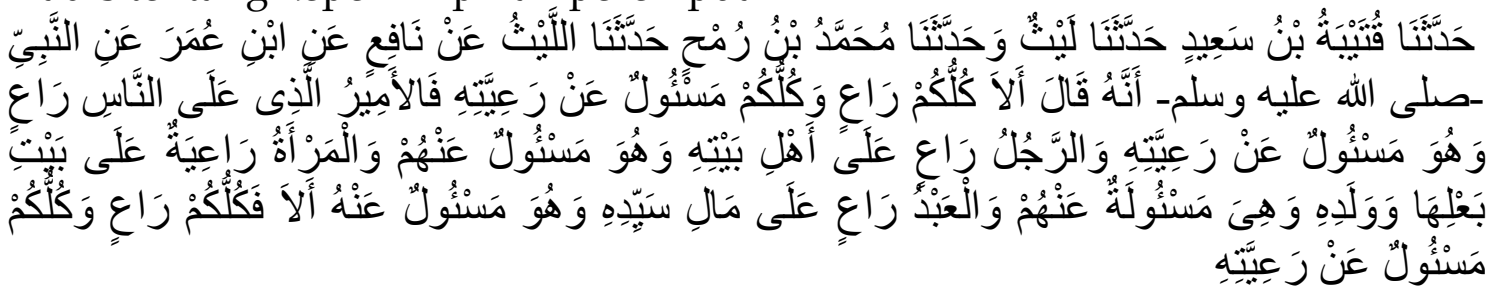

Artinya:

Dari berbagai jalan dari Nafi' dari Ibnu Umar dari Nabi SAW bersabda: Setiap kamu adalah pemimpin dan bertanggung jawab atas kepemimpinannya, kepala negara adalah pemimpin bagi rakyatnya dan dia bertanggung jawab atas kepemimpinannya, laki-laki adalah pemimpin atas keluarganya dan dia bertanggung jawab atas kepemimpinannya, wanita adalah pemimpin di rumah suaminya dan anak-anaknya dan dia bertanggung jawab atas kepemimpinannya, dan seorang hamba adalah pemimpin atas harta tuannya dan dia bertanggung jawab atas kepemimpinannya. Maka setiap kamu adalah pemimpin dan bertanggung jawab atas kepemimpinanmu itu.

Al-Quran dan Hadis menjelaskan hak seorang perempuan dalam hal memberikan pengabdian kepada agama, nusa dan bangsa serta pertimbangan kualitas, kuantitas akseptabilitas yang menjadi pertimbangan perempuan menjadi pemimin. Dalam sejarah Islam, perempuan tampil sebagai seorang pemimpin dan ilmuan yang sangat dihormati seperti Aisyah ra. Sebagai salah satu seorang inteletual dan aktivis yag berani memimpin perang dan menjadi sumber pengetahuan.

Perempuan dalam kehidupan bermasyarakat sangat jelas, yakni memiliki hak dan kewajiban membentuk masyarakat yang adil, sejahtera dan makmur. Aktif dalam dalam aktivitas yang bertujuan membangun masyarakat baldatun 
thayyibatun wa rabbun ghafur. ${ }^{12}$ Aktifitas yang diemban perempuan tentu harus pandai membagi waktu untuk kepentingan diri sendiri, keluarga dan kepentingan masyarakat bahkan jangan sampai melakukan hal sebaliknya yakni mementingkan diri sendiri, masa bodoh, bersifat apatis, hanya menjadi penonton terhadap soalan ditengah masyarakat adalah hal yang mesti dihindari sebagai seorang perempuan. Tugas utama manusia diciptakan baik perempuan maupun laki-laki adalah menjadi pemimpin, yakni mampu memimpin diri sendiri dalam keluarga dan masyarakat, agar nantinya dapat berguna dan bermanfaat.

\section{b. Perempuan bugis sebagai istri dan ibu}

Perempuan bugis sebagai seorang isteri ${ }^{13}$ yang taat terhadap suaminya, memegang teguh nilai-nilai agama, dan saling mencintai yang dicitrakan sebagai perempuan setia sehingga hal itu bisa dilihat dalam naskah yang diperpegangi sebagai panutan sebagai tugas utama dari perempuan bugis diantara:

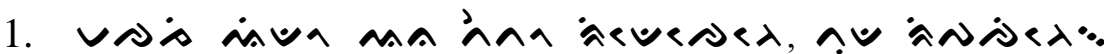

(Mancaji Indo Ana' tettong ridécéngngé tudang ripacingngé)

Terjemahan: Menjadi seorang ibu yang sholeh dan suci

Islam menempatkan perempuan sebagai mitra yang sejajar dengan lakilaki dalam berkeluarga melalui perkawinan, untuk mewujudkan sakinah mawaddah dan wa rahmah. Dalam mewujudkannya al-Quran telah memberikan petunjuk bagi suami dan isteri. yakni bagi suami terdapat pada Q.S. an-Nisa/4: 19:

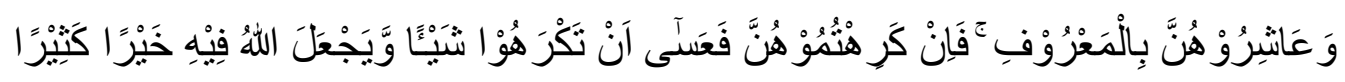

Terjemahan:

Dan bergaullah dengan mereka menurut cara yang patut. Jika kamu tidak menyukai mereka, (maka bersabarlah) karena boleh jadi kamu tidak menyukai sesuatu, padahal Allah menjadikan kebaikan yang banyak padanya.

Q.S. al-Baqarah /2:228

Terjemahan:

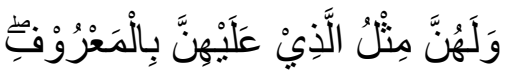

Dan mereka (para perempuan) mempunyai hak seimbang dengan kewajibannya menurut cara yang patut.

Ayat di atas menggambarkan garis pembatas dalam hubungan suami isteri harus berdasarkan muāsyarah bi al-ma'rüf yang diartikan sebagai pergaulan, pertemanan, persahabatan, kekeluargaan dan kekerabatan yang dibangun bersama dengan cara yang baik. Pesan moral agama ini bagi peran

${ }^{12}$ Musda Mulia, Kemuliaan Perempuan dalam Islam (Cet. II; Megawati Institut, 2014), h. 65

13 Kedudukan perempuan bugis merupakan lambang kehormatan dalam kehidupan keluarga karena dalam kenyataannya orang bugis bersedia mati untuk membela kehormatan wanita yang telah dihina oleh orang lain di masyarakat. Hamid Abdullah, Manusia Bugis Makassar (Cet. I; Jakarta: Inti Idayu Press, 1985), h. 70. 
perempuan sebagai seorang isteri agar di masa perkawinan tidak menimbulkan masalah yang tidak diinginkan justru menjadi seorang isteri tentu harus mendatangkan kemaslahatan untuk diri dan keluarga besar kedua belah pihak dan masyarakat.

Kebutuhan perempuan akan dunia luar tercermin dari peran perempuan sebagai isteri dan ibu menjaga rumah tangga tentram serta peran perempuan di sosial kemasyarakatan sebagai bekal maka dibutuhkan kemampuan pendidikan yang diperoleh melalui aktifitas belajar seperti mengenyam pendidikan yang layak, mengikuti ceramah, membaca buku, mengikuti pengajian-pengajian serta meningkatkan kualitas pengetahuannnya dalam bentuk yang lain. Pendidikan ini hanya akan di dapatkan jika seorang perempan berinteraksi dilingkungan masyarakat sehinga dalam berumahtangga nantinya harus memiliki kualitas, pengalaman, wawasan luas, memiliki keterampilan dan paling penting berahlak karimah.

Seorang isteri dan suami memiliki kesetaran dengan suami sebagaimana prinsip dalam perkawinan yakni prinsip komitmen yang sangat kuat (mitsaqan galiza); prinsip saling mencintai dan saling mengasihi sepenuh hati (mawaddah wa rahmah); prinsip saling menghormati, sopan santun penuh kelembutan (mu'asyarah bil ma'ruf); prinsip kesetaraan dan kesederajatan (al-musawah) dan prinsip keadilan ( $a l-A d l)$

Perempuan sebagai isteri berhak mendapatkan dan memberikan kebahagian, peran lain sebagai isteri bersama dengan suami, bertanggung jawab akan tugas rumah tangga maupun tugas di luar rumah. Seorang isteri berhak mendapatkan perlindungan disaat melaksanakan tugas kodratinya bukan hanya dari suami namun dari keluarga, masyarakat dan tentunya negara. Di Indonesia telah memberikan ruang bagi perempuan yang sementara hamil atau setelah melahirkan dengan ketentuan regulasi yang ada untuk mendapatkan cuti supaya lebih fokus kepada keluarga.

2.

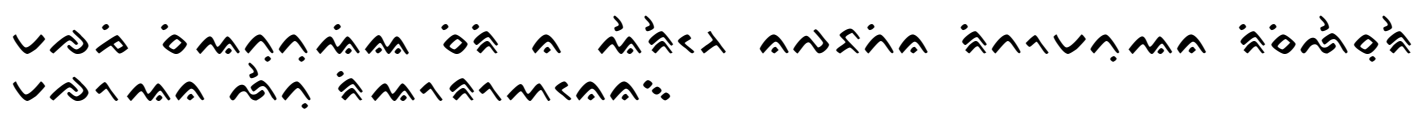

(Mancaji 'siatutuiang siri na enrengngé napabbatina ritomatoanna, risiléssureng macoana lettu' riorowanéna)

Terjemahan : menjaga kehormatan diri dan keluarga, menjadi kebanggaan ayahnya, saudaranya, suaminya.

Perempuan sebagai isteri menjadi kebanggaan, kesucian, kesholehan dalam keluarga masyarakat bugis. Hal ini sejalan dengan ajaran Islam bahwa posisi perempuan sebagai isteri sekaligus ibu bagi anak-anaknya sangat mulia. Surga dibawah kaki ibu artinya kebahagian, keselamatan, kesuksesan, seseorang yang amat menentukan adalah ridha seorang Ibu. Sebagaimana penghormatan yang disebutkan dalam hadis nabi saw. bahwa penghormatan seorang anak lebih kepada ibunya, selanjutnya kepada ayahnya.

Hukum keluarga Islam mengatur peran kodrati bagi ibu seperti mengandung, melahirkan dan menyusui dan peran suami memberikan 
perlindungan, bantuan agar peran tersebut berjalan lancar sebagaimana firman Allah dalam Q.S. al-Baqarah/2: 233:

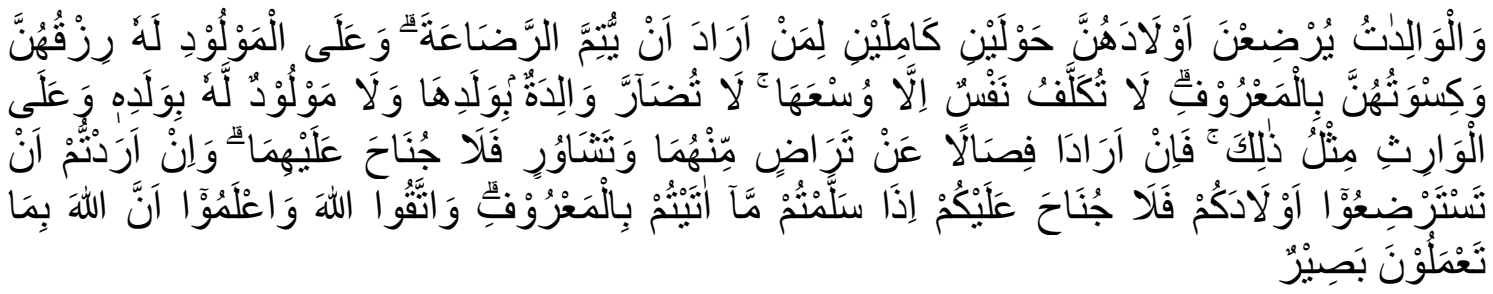

Terjemahan:

Dan ibu-ibu hendaklah menyusui anak-anaknya selama dua tahun penuh, bagi yang ingin menyusui secara sempurna. Dan kewajiban ayah menanggung nafkah dan pakaian mereka dengan cara yang patut. Seseorang tidak dibebani lebih dari kesanggupannya. Janganlah seorang ibu menderita karena anaknya dan jangan pula seorang ayah (men-derita) karena anaknya. Ahli waris pun (berkewajiban) seperti itu pula. Apa-bila keduanya ingin menyapih dengan persetujuan dan permusyawaratan antara keduanya, maka tidak ada dosa atas keduanya. Dan jika kamu ingin menyusukan anakmu kepada orang lain, maka tidak ada dosa bagimu memberikan pembayaran dengan cara yang patut. Bertakwalah kepada Allah dan ketahuilah bahwa Allah Maha Melihat apa yang kamu kerjakan.

Perempuan bugis sebagai ibu sangat ditekankan untuk menjadikan anakanaknya sebagai anak yang berbakti dan patuh pada orang tuanya. Ibu mengasuh, mendidik menasehati anak-anaknya bahkan kebiasaan perempuan bugis dalam mengasuh disertai pappaseng, dan elokkelong. Pappaseng adalah petuah-petuah orang tua disampaikan kepada anak dijadikan sebagai tuntunan hidupnya kelak. ${ }^{14}$ Sedangkang elokkelong atau elong $p a^{\prime}$ dondodondo adalah nyanyian yang berisikan doa dan harapan dikhususkan orang tua kepada anaknya, dilakukan pada saat ibu sedang menjaga dan menidurkan anaknya. Selanjutnya mengajarkan anak-anaknya membaca dan menulis, mengajarkan ilmu agama dan ilmu lainnya.

Hukum keluarga Islam mengedepankan perempuan sebagai manusia bijak yang bisa melakukan peran multifungsi. Perempuan bugis mulai dari datangnya Islam di tanah bugis mengalami transformasi budaya dan pertautan adat istiadat yang sangat ketat. Islam dan budaya serta adat istiadat berjalan seiring dan saling melengkapi. Keberadaan perempuan Bugis tidak dipungkiri keberadaanya dalam pemerintahan dan kepemimpinan. Perempuan bugis

14 Ungkapan dalam bentuk pappaseng yang bernilai kecerdasan dan kejujuran seperti: $\wedge$ s

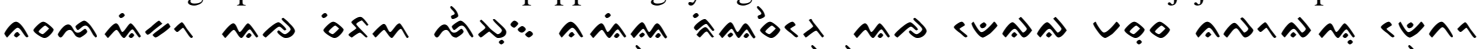

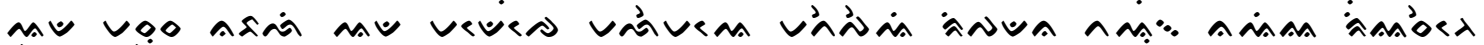

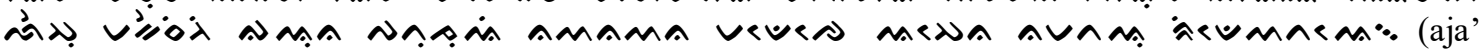
nasalaiko' acca' sibawa lempuq (naiyya riyasengge acca deqgaga masussa napogau deqto ada masussa nabali, ada madeceng malemma'e, mateppe'I ri padanna tauw. Naiyya riyasengge lempuq, makessinggi gau'na, patujui nawa-nawanna, madeceng ampena, namatau ri dewata'e). Terjemahan: hal yang penting harus dimiliki adalah kecerdasan dan kejujuran. Dengan kecerdasan semua pekerjaan menjadi mudah, semua persoalan terselesaikan dengan kalimat yang baik dan santun. Saling percaya pada sesama. Kejujuran merupakan melakukan perbuatan yang baik, berprasangka yang baik, berlaku sopan, dan bertaqwa kepada Allah swt. 
mampu melaksanakan tugas sesuai kodratnya sebagai istri dan ibu dalam kesehariaanya disamping sebagai pemimpin dalam pemerintahan. Perempuan Bugis mampu mengaplikasikan nilai-nilai agama dan tetap mempertahankan identitasnya sebagai perempuan yang mempunyai budaya siri', sipakatau, sipakalebbi, sipakainge setiap tingkah laku dan keseharian mereka.

\section{PENUTUP}

Identitas perempuan bugis yakni siri', sipakatau, sipakalebbi, sipakainge. Peran perempuan bugis dalam masyarakat dipetakan menjadi dua yakni pertama peran perempuan bugis sebagai pemimpin. Kedua peran perempuan bugis sebagai isteri sekaligus ibu. Perspektif hukum keluarga Islam mengatur bahwa peran perempuan bugis baik dalam rumah tangga maupun di ranah publik ajarannya tetap mengedepankan keadilan kesetaraan dan demokrasi.

\section{DAFTAR PUSTAKA}

Abdullah, Hamid. Manusia Bugis Makassar Suatu Tinjauan Historis Pola Tingka Laku dan PAndangan Hidup Manusia Bugis Makassar. Cet. I; Jakarta: Inti Idayu Press, 1985.

al Zuhailî, Wāhbah. al-Fiqh al-Islāmī wa Adillatuh. Beirūt-Lubhān: Dār al-Fikr, 1989.

Al-Quran dan Hadis.

Dzuhayanti, Siti Ruhaini. Rezim Gender Muhammadiah Kontestasi Gender, Identitas dan Eksistensi. Cet. I; Yogyakarta: Pustaka Pelajar, 2015.

Firth. Raymond, Elements of Sosial Organization. Boston: Beacon Press, 1961.

Illich, Ivan. Matinya Gender. Cet. VI; Yogyakarta: Pustaka Pelajar, 2007.

Jufri. Analisis Wacana Budaya. Cet. I; Makassar: Badan Penerbit UNM, 2009.

La Paroki, Perempuan Bugis (online), http://www.Identitasonline.net/2012/04/Perempuan-bugis html diunduh 14 januari 2013.

Makmur, Jamal. Resim Gender di NU. Cet. I; Yogyakarta: Pustaka Pelajar, 2015.

Mattulada. Latoa Satu Lukisan Analitis terhadap Antropologi Politik Orang Bugis. Gadjah Mada University Press 1985.

Mulia, Musdah. Indahnya Islam Menyuarakan Keseteraan \& Keadilan Gender. Cet. I; Yogyakarta: Nauvan Pustaka bekerja sama Megawati Institut, 2014.

Mulia, Musdah. Kemulian Perempuan dalam Islam. Cet; II; Megawati Institut bekerjasama Bima Optima.

Pelras, Christian. The Bugis, yang diterjemahkan Abdul rahman Abu, dalam judul Manusia Bugis. Jakarta: Nalar bekerjasama dengan Forum JakartaParis, 2005.

Rahim, Rahman. Nilai-Nilai Utama Kebudayaan Bugis. Cet. I; Ombak: Yogyakarta, 2011. 
Rofiq, Ahmad. Hukum Islam Indonesia, Edisi I. Cet. III; Jakarta: Pt. Raja Grafindo Persada, 1998.

Sa'dawi, Amru Abdul karim. Qaḍayā Mar'ati fi Fiqh al Qardawi, dalam terjemahannya Muhyiddin Mas Rida, Perempuan dalam Fikih Al-Qaraqhawi. Cet.1; Jakarta: Pustaka al-Kausar, 2009.

Suma, Muhammad Amin. Hukum Keluarga Islam di Dunia Islam. Jakarta: PT RajaGrafindo Persada, 2005. 